\title{
Establishment of Leaf Tissue Nutrient Sufficiency Ranges of Two Perovskia Selections by Chronological Age
}

\author{
W. Garrett Owen \\ Department of Horticulture, University of Kentucky, N-310D Agriculture \\ Science Center North, Lexington, KY 40546
}

Additional index words. greenhouse production, macronutrient, micronutrient, nitrogen, perennial, plant nutrition, Russian sage

\begin{abstract}
The objective of this study was to determine optimum fertilizer concentrations, identify leaf tissue nutrient sufficiency ranges by chronological age, and establish leaf tissue nutrient standards of containerized Russian sage (Perovskia sp.). Common Russian sage ( $P$. atriplicifolia Benth.) and 'Crazy Blue' Russian sage were greenhouse-grown in a soilless substrate under one of six constant liquid fertilizer concentrations $[50,75,100$, 200,300 , or $400 \mathrm{mg} \cdot \mathrm{L}^{-1}$ nitrogen $\left.(\mathrm{N})\right]$ with a constant level of a water-soluble micronutrient blend. Fertilizer concentrations sufficient for optimal plant growth and development were determined by analyzing plant height, diameter, growth index, primary shoot caliper, axillary shoot number, and total dry mass; they were found to be 100 to 200 mg. $\mathrm{L}^{-1} \mathrm{~N}$ after a 6 -week crop cycle. Recently, mature leaf tissue samples were collected from plants fertilized with 100 to $200 \mathrm{mg} \cdot \mathrm{L}^{-1} \mathrm{~N}$ and analyzed for elemental contents of 11 nutrients at 2, 4, and 6 weeks after transplant (WAT). An overall trend of increasing foliar nutrient concentrations over time was observed for all elemental nutrients. For instance, at 2 WAT, the total $N$ concentrations of common Russian sage and ' $C$ razy Blue' Russian sage ranged between $3.68 \%$ and $5.10 \%$ and between $3.92 \%$ and $5.12 \%$, respectively, and increased to ranges of $5.94 \%$ to $5.98 \%$ and $5.20 \%$ to $5.86 \%$ at 6 WAT, respectively. Before this study, no leaf tissue concentration standards have been reported; therefore, this study established leaf tissue concentration sufficiency ranges for the trialed Perovskia selections.
\end{abstract}

Russian sage (Perovskia sp.) is a popular ornamental herbaceous perennial grown for its fragrant blue flowers, drought and salt tolerance, deer resistance, and use as a pollinator plant (personal observation); its reported wholesale value was $\$ 3.8$ million in 2014 (U.S. Department of Agriculture, 2015). To produce high-quality containerized plants, greenhouse growers must optimize production inputs such as fertilization (Owen, 2019a, 2019b). To date, mineral nu-

Received for publication 7 May 2020. Accepted for publication 4 June 2020.

Published online 6 July 2020

I gratefully acknowledge Kyle Martin for greenhouse assistance and Dr. James Altland and Erin Lowe for substrate analysis. I thank Walters Gardens, Inc., for plant material; Barson's Greenhouse for substrate; Bordine's Farm for the fertilizers; and the Fred C. Gloeckner Foundation, Inc. and Michigan State University Extension Agriculture and Agribusiness Institute (AABI) Generating Research and Extension to meet Economic and Environmental Needs (GREEEN) Research for funding support.

The use of trade names in this publication does not imply endorsement by the University of Kentucky or University of Kentucky Extension of products named nor criticism of similar ones not mentioned. W.G.O. is the corresponding author. E-mail: wgowen@ uky.edu.

This is an open access article distributed under the CC BY-NC-ND license (https://creativecommons. org/licenses/by-nc-nd/4.0/). trition recommendations for commercially grown Perovskia do not exist. Generally, growers of herbaceous perennials will provide crops with water-soluble fertilizer applications of 50 to $250 \mathrm{mg} \cdot \mathrm{L}^{-1}$ nitrogen $(\mathrm{N})$ on a continual basis or 150 to $700 \mathrm{mg} \cdot \mathrm{L}^{-1} \mathrm{~N}$ applied weekly (Pilon, 2006). The philosophy of this approach involves monitoring the inputs to the crop and, as long as the substrate inputs are within the recommended range, e.g., substrate $\mathrm{pH}$ and electrical conductivity (EC), it is assumed that the fertility requirements of the crop are being met (Krug et al., 2010; Owen, 2019b). However, these fertility recommendations vary greatly, are not species-specific, and may result in deficient or excessive fertility levels provided to crops.

During containerized plant production, deficient or excessive fertility levels of essential nutrients can influence plant growth and induce deficiency or toxicity symptomology, thus compromising the overall plant quality. Greenhouse growers often rely on leaf tissue analyses (Krug et al., 2010) to either determine nutrient status or target and identify nutritional disorders (Owen and Whipker, 2020). Results of leaf tissue analyses can be compared with known speciesspecific nutritional leaf tissue sufficiency ranges and standards (Bryson and Mills, 2014); however, for the taxa Perovskia, sufficiency ranges do not exist. However, Biernbaum and Morrison (2000) published survey values obtained from mature leaves of com- mon Russian sage ( $P$. atriplicifolia Benth.) grown under greenhouse conditions in soilless substrates and provided with an unknown concentration of mineral nutrition. Therefore, these nutritional values do not accurately represent the nutritional status or sufficiency range of the taxa Perovskia or cultivars commercially produced by greenhouses. Furthermore, little attention has been given to identifying nutritional sufficiency ranges of container-grown Perovskia by chronological age.

Leaf tissue nutrient sufficiency ranges by chronological age for herbaceous perennials have only been reported for perennial hibiscus (Hibiscus hybrid L. 'Mocha Moon' and 'Starry Starry Night'; Owen, 2019a) and coral bells (Heuchera hybrida L. 'Black Beauty', 'Cherry Cola', 'Marmalade', and 'Peppermint Spice'; Owen, 2019b). For annual bedding plants, leaf tissue nutrient sufficiency ranges by chronological age have been reported for coleus [Plectranthus scutellarioides (L.) Codd 'Broad Street', 'Stained Glass Eruption', and 'Wall Street'; Henry et al., 2019], gerbera (Gerbera jamesonii Bolus ex Hook. f. 'Festival Light Eye Yellow'; Jeong et al., 2009), osteospermum (Osteospermum hybrida L. 'Lemon Symphony', 'Serenity Lavender Dark', 'Summertime Red Velvet', and 'Tradewinds Purple Bicolor'; Papineau and Krug, 2014), zonal geranium (Pelargonium $\times$ hortorum L.H. Bailey 'Tango Dark Red' and 'Rocky Mountain Dark Red'; Krug et al., 2010), and 74 other floriculture species (Whipker et al., 2017). Regarding agronomic and field vegetable crops, Campbell (2000) reported leaf nutrient sufficiency ranges by chronological age for bell pepper (Capsicum annuum L.), cantaloupe (Cucumis melo L.), corn (Zea mays L.), grain sorghum [Sorghum bicolor (L.) Moench sp. bicolor], and burley and fluecured tobacco (Nicotiana tabacum L.). Nonetheless, determining sufficiency ranges by chronological age for the taxa Perovskia will define fertilizer recommendations, thereby enabling growers to optimize production inputs. Therefore, the objectives of this study were to determine the optimum fertilizer concentrations, identify leaf tissue nutrient sufficiency ranges by chronological age, and establish leaf tissue nutrient standards of containerized Perovskia grown in a soilless substrate.

\section{Materials and Methods}

Plant material and culture. On 8 April, 72-cell plug trays $(30.7 \mathrm{~mL}$ individual cell volume) of common Russian sage (Perovskia atriplicifolia) and 'Crazy Blue' Russian sage were received from a commercial propagator (Walters Gardens, Inc., Zeeland, MI). Young plants of each taxa with similar heights, stem caliper, and node numbers were selected and transplanted as one plant per $16.5-\mathrm{cm}$ diameter container (1.9 L volume; Landmark Plastic Corp., Akron, OH). Containers were filled with premoistened commercial soilless peat-based substrate comprising (by volume) 
$65 \%$ peat, $20 \%$ perlite, and $15 \%$ vermiculite amended with dolomitic limestone, wetting agent, and a starter nutrient charge with gypsum (Fafard 2; Sun Gro Horticulture, Agawam, MA). Substrate physical properties were determined using three representative samples that were analyzed using the North Carolina State University porometer procedure (Fonteno et al., 1995). Physical properties of the substrate were (by volume) $8.2 \pm$ $0.9 \%$ air space, $77.7 \pm 0.7 \%$ total porosity, $69.2 \pm 0.7 \%$ container capacity, and 0.09 $\mathrm{g} \cdot \mathrm{cm}^{-3}$ bulk density. Plants were irrigated to container capacity with water supplemented with 35\% sulfuric acid (AutoCraft Battery Acid; Johnson Controls Battery Group, Milwaukee, WI) at $0.16 \mathrm{mg} \cdot \mathrm{L}^{-1}$ to neutralize alkalinity from 4.0 to $1.6 \mathrm{meq} \cdot \mathrm{L}^{-1}$ calcium carbonate $\left(\mathrm{CaCO}_{3}\right)$ and reduce $\mathrm{pH}$ from 7.3 to a range of 5.8 to 6.0 .

Plant fertility. Thirty-six plants of each taxa were placed on one of four greenhouse benches. Each bench was equipped with three independently controlled benchtop $1.9-\mathrm{cm}$ black irrigation lines fitted with $2412-\mathrm{cm}$ diameter drip rings (Dramm USA, Manitowoc, WI) that were placed on top of the substrate of each container corresponding to one of six fertilizer concentrations. Each of the six fertilizer concentrations was replicated twice for a total of 12 irrigation lines that were randomized in two blocks, with each consisting of two benches. Irrigation lines were connected to sump-pumps (model 1A; Little Giant Pump Co., Oklahoma City, $\mathrm{OK})$ that delivered one of six constant liquid fertilizer concentrations [50, 75, 100, 200, 300 , or $400 \mathrm{mg} \cdot \mathrm{L}^{-1}$ nitrogen $\left.(\mathrm{N})\right]$ based on balanced ratios of $\mathrm{N}$-phosphorous (P)potassium $(\mathrm{K})$ supplied by $15 \mathrm{~N}-1.7 \mathrm{P}-12.5 \mathrm{~K}$ (GreenCare Bordine's Special; Blackmore Co., Belleville, MI) containing 1.9\% ammoniacal $\left(\mathrm{NH}_{4}^{+}\right)-\mathrm{N}$ and $13.1 \%$ nitrate $\left(\mathrm{NO}_{3}{ }^{-}\right)-\mathrm{N}$ without micronutrients. Fertilizer concentrations were selected based on grower practice and to determine minimum and maximum sufficiency ranges.

Regardless of the $\mathrm{N}$ fertilizer treatment, plants received a constant level of a watersoluble micronutrient blend (GreenCare Bordine's Special; Blackmore Co.) supplying (in $\left.\mathrm{mg} \cdot \mathrm{L}^{-1}\right) 2.0$ iron $(\mathrm{Fe}), 0.5$ manganese $(\mathrm{Mn})$ and zinc ( $\mathrm{Zn}$ ), 0.25 boron (B) and copper $(\mathrm{Cu})$, and 0.1 molybdenum (Mo). The watersoluble micronutrient blend did not contain macronutrients. The water-soluble fertilizer and micronutrient blend were weighed and dissolved together in individual 100-L barrels by fertilizer concentration treatment. Plants were irrigated as needed to the point of leaching and were never allowed to dry out. Each month, plants received a $150-\mathrm{mL}$ drench containing $50 \mathrm{mg} \cdot \mathrm{L}^{-1}$ magnesium sulfate $\left(\mathrm{MgSO}_{4} \cdot 7 \mathrm{H}_{2} \mathrm{O}\right)$. No solution was leached or drained from the containers after application.

Greenhouse environment. Plants were grown in a greenhouse covered in doublepolyethylene with roll-up side curtains [Novi, MI (lat. $42^{\circ} \mathrm{N}$ )] at $20{ }^{\circ} \mathrm{C}$ under ambient daylight supplemented with a photosynthetic photo flux density (PPFD) of $\approx 33.8$ $\mu \mathrm{mol} \cdot \mathrm{m}^{-2} \cdot \mathrm{s}^{-1}$ at plant height as measured with a quantum sensor (LI-COR Biosciences) delivered from $150-\mathrm{W}$ high-pressure sodium (HPS) lamps (Sun System HPS 150 Grow Light Fixture; Sunlight Supply, Inc., Vancouver, WA) from 0600 to $2200 \mathrm{HR}$ (16-h photoperiod). On each bench, an enclosed thermocouple recorded air temperature every $30 \mathrm{~s}$ and averages were logged every $15 \mathrm{~min}$ by a data logger (WatchDog Model 2475 Plant Growth Station; Spectrum Technologies, Inc., Aurora, IL). Line quantum sensors (SQ-316-SS; Apogee Instruments, Inc., Logan, UT) mounted $60 \mathrm{~cm}$ above the benchtop measured PPFD every $30 \mathrm{~s}$, and the average of each sensor was logged every $15 \mathrm{~min}$ by a data logger (WatchDog 2800 Weather Station; Spectrum Technologies, Inc.). Average daily light integral, air temperature, and relative humidity throughout the 6-week duration of the experiment were $11.9 \pm 4.4 \mathrm{~mol} \cdot \mathrm{m}^{-2} \cdot \mathrm{d}^{-1}, 21.6 \pm 2.5{ }^{\circ} \mathrm{C}$, and $64.6 \pm 5.8 \%$, respectively.

Growth and nutritional data and calculations. Data regarding three randomly selected experimental units (individual plants) of each taxa were collected. Data were collected at 2 (young growth), 4 (active growth), and 6 (mature growth and/or bloom) WAT. At each collection date, substrate solution was extracted $1 \mathrm{~h}$ after irrigation using the PourThru method (Cavins, 2002) and analyzed to determine $\mathrm{pH}$ and $\mathrm{EC}$ using a hand-held $\mathrm{pH}$ and $\mathrm{EC}$ meter (HI 9813-6; Hanna Instruments, Woonsocket, RI). Plant height was determined by measuring from the substrate surface to the apical meristem (2 and 4 WAT) or inflorescence (6 WAT). Plant diameter was determined by measuring the widest dimension and the axis perpendicular to the widest dimension and averaging. The growth index $\{\mathrm{GI} ;$ [GI $=$ (plant height + plant diameter $\div$ 2] $\}$ was calculated for each plant. At 6 WAT, the primary shoot caliper (PSC) was determined by measuring below the lowest axillary shoot with a digital caliper (digiMax; Wiha, Schönach, Germany). The axillary shoot number was determined by counting axillary shoots more than 1 inch below the apical meristem or inflorescence.

At 2, 4, and $6 \mathrm{WAT}$, the recently mature (youngest fully expanded) leaves were removed from the selected three experimental units from each Russian sage. Leaves were washed in a solution of $0.5 \mathrm{~N}$ hydrochloric acid $(\mathrm{HCl})$ for $1 \mathrm{~min}$ and rinsed in deionized water before being individually bagged and dried in an oven at $70{ }^{\circ} \mathrm{C}$ for 1 week. After 1 week, dried tissue was weighed to determine young leaf dry mass (YDM) and ground with a mortar and pestle to pass a $\leq 0.5-\mathrm{mm}$ sieve, placed in $15-\mathrm{mL}$ polypropylene conical centrifuge tubes (Falcon $17 \times 120 \mathrm{~mm}$; Corning, Corning, NY), and analyzed for nutrient concentrations by AgSource Laboratories (Lincoln, NE). Total $\mathrm{N}$ was processed by Kjeldahl digestion and determined by flow injection analysis (FIA). Extractable $\mathrm{K}$ was processed by $2 \%$ acetic acid digestion and determined by inductively coupled plasma mass spectrometry (ICP-MS). Total P and all other plant minerals [Ca, Mg, Fe, Mn, Zn, B, $\mathrm{Cu}$, and aluminum (Al)] were processed by nitric acid/hydrogen peroxide digestion and determined by ICP-MS.

The remaining plant tissues were destructively harvested by severing the stem at the substrate surface, individually bagging, and drying in an oven at $70{ }^{\circ} \mathrm{C}$. After 1 week, plant dry mass (PDM) was determined. Total PDM [TDM; (TDM = YDM + PDM)] was calculated for each plant.

Experimental design and statistical analyses. The experiment was laid out in a randomized complete block design with two blocks and six fertilizer concentrations arranged in a split plot with two replications within each split plot. Plants of each taxa were randomized within each replication. There were three experimental units per taxa per fertilizer concentrations per replication. Within each block, no significant differences occurred among replications per taxa; therefore, data were pooled. Effects of fertilizer concentrations per taxa were analyzed using the SAS (version 9.2; SAS Institute, Cary, NC) general linear model procedure (PROC GLM) for analysis of variance. For each taxa, regression analyses of plant height, diameter, GI, PSC, axillary shoot number, and TDM at 6 WAT were performed using the SAS regression procedure (PROC REG). For all analyses, $P \leq 0.05$ was used to determine significant effects.

\section{Results and Discussion}

Sufficiency range. At 6 WAT, increasing fertilizer concentrations significantly influenced the diameter, GI, PSC, axillary shoot number, and TDM, but not plant height, of both Perovskia selections. Growth data were analyzed to determine lower and upper nutritional limits for each taxa. Plants of both Perovskia selections fertilized with 50 and 75 $\mathrm{mg} \cdot \mathrm{L}^{-1} \mathrm{~N}$ resulted in similar and significantly smaller plants than those fertilized with 100 to $400 \mathrm{mg} \cdot \mathrm{L}^{-1} \mathrm{~N}$. For instance, GI and TDM of 'Crazy Blue' Russian sage grown at 50 to $75 \mathrm{mg} \cdot \mathrm{L}^{-1} \mathrm{~N}$ were $17 \%$ to $19 \%(4.9-5.5 \mathrm{~cm})$ and $46 \%$ to $79 \%(8.2-13.9 \mathrm{~g})$ smaller, respectively, than plants fertilized at 100 $\mathrm{mg} \cdot \mathrm{L}^{-1} \mathrm{~N}$. Therefore, $100 \mathrm{mg} \cdot \mathrm{L}^{-1} \mathrm{~N}$ was determined as the lower nutritional limit (Table 1; Figs. 1 and 2); plants fertilized with 50 and $75 \mathrm{mg} \cdot \mathrm{L}^{-1} \mathrm{~N}$ were excluded from further statistical analyses.

For both taxa, the plant growth response was similar among ascending fertilizer concentrations from 100 to $200 \mathrm{mg} \cdot \mathrm{L}^{-1} \mathrm{~N}$ (Table 1); with more than $200 \mathrm{mg} \cdot \mathrm{L}^{-1} \mathrm{~N}$, growth declined. For instance, the TDM of common Russian sage and 'Crazy Blue' Russian sage at fertilizer concentrations of 200 to $400 \mathrm{mg} \cdot \mathrm{L}^{-1} \mathrm{~N}$ decreased by $53.1 \%$ (9.4 g) and $57.2 \%(8.7 \mathrm{~g})$, respectively. Decreasing TDM at 300 and $400 \mathrm{mg} \cdot \mathrm{L}^{-1} \mathrm{~N}$ is likely attributed to the accumulation of soluble salts and the sensitivity of an elevated substrate EC (Scoggins, 2005). This is consistent with the results of Owen (2019a, 2019b), who 
Table 1. Average plant height, diameter, growth indices (GI), primary shoot caliper (PSC), axillary shoots, and total plant dry mass (TDM) for common Russian sage (Perovskia atriplicifolia Benth.) and 'Crazy Blue' Russian sage. Plants were grown under one of six constant liquid fertilizer concentrations [50, $75,100,200,300$, or $400 \mathrm{mg} \cdot \mathrm{L}^{-1}$ nitrogen $\left.(\mathrm{N})\right]$ based on balanced ratios of $\mathrm{N}$-phosphorous $(\mathrm{P})$ potassium $(\mathrm{K})$ supplied by $15 \mathrm{~N}-1.7 \mathrm{P}-12.5 \mathrm{~K}$ containing $1.9 \%$ ammoniacal- $\mathrm{N}$ and $13.1 \%$ nitrate- $\mathrm{N}$ with a constant level of water-soluble micronutrient blend in a greenhouse. Plants $(n=6)$ were harvested six weeks after transplant (WAT) at maturity (bloom).

\begin{tabular}{|c|c|c|c|c|c|c|}
\hline $\begin{array}{l}\text { Nitrogen (N) concn } \\
\left(\mathrm{mg} \cdot \mathrm{L}^{-1} \mathrm{~N}\right)\end{array}$ & $\begin{array}{l}\mathrm{Ht}^{2} \\
(\mathrm{~cm})\end{array}$ & $\begin{array}{c}\operatorname{Diam}^{y} \\
(\mathrm{~cm})\end{array}$ & $\begin{array}{l}\mathrm{GI}^{\mathrm{x}} \\
(\mathrm{cm})\end{array}$ & $\begin{array}{l}\mathrm{PSC}^{\mathrm{w}} \\
(\mathrm{mm})\end{array}$ & $\begin{array}{c}\text { Axillary } \\
\text { shoots }^{\mathrm{v}} \text { (no.) }\end{array}$ & $\begin{array}{c}\mathrm{TDM}^{\mathrm{u}} \\
(\mathrm{g})\end{array}$ \\
\hline \multicolumn{7}{|l|}{ Common Russian sage } \\
\hline 50 & 65.9 & 26.1 & 30.8 & 4.0 & 4.0 & 15.2 \\
\hline 75 & 68.8 & 26.5 & 31.7 & 4.1 & 4.7 & 21.6 \\
\hline 100 & 85.7 & 35.3 & 40.3 & 4.2 & 6.3 & 29.3 \\
\hline 200 & 88.7 & 36.5 & 41.7 & 4.4 & 8.3 & 36.8 \\
\hline 300 & 83.8 & 34.9 & 39.6 & 4.8 & 7.7 & 31.2 \\
\hline 400 & 80.2 & 31.2 & 37.1 & 4.4 & 7.0 & 28.1 \\
\hline Significance $^{t}$ & NS & $\mathrm{Q}^{*}$ & $\mathrm{Q}^{*}$ & $\mathrm{Q}^{*}$ & $\mathrm{Q}^{*}$ & $\mathrm{Q}^{* *}$ \\
\hline \multicolumn{7}{|c|}{ 'Crazy Blue' Russian sage } \\
\hline 50 & 65.0 & 29.2 & 31.4 & 4.0 & 3.3 & 17.7 \\
\hline 75 & 71.8 & 28.6 & 33.5 & 4.1 & 5.7 & 23.4 \\
\hline 100 & 77.6 & 34.1 & 37.3 & 4.3 & 6.7 & 31.6 \\
\hline 200 & 82.8 & 37.4 & 40.1 & 5.2 & 9.0 & 39.5 \\
\hline 300 & 81.0 & 35.6 & 38.9 & 4.7 & 8.3 & 34.1 \\
\hline 400 & 75.2 & 35.3 & 36.8 & 4.5 & 4.0 & 30.1 \\
\hline Significance & NS & $\mathrm{Q}^{* * *}$ & $\mathrm{Q}^{* *}$ & $\mathrm{Q}^{*}$ & $\mathrm{Q}^{*}$ & $\mathrm{Q}^{* *}$ \\
\hline
\end{tabular}

${ }^{\mathrm{z}}$ Plant height (ht) measured from the substrate surface to the apical meristem.

${ }^{\mathrm{y}}$ Plant diameter (diam) determined by measuring the widest dimension and the axis perpendicular to the widest dimension and averaged.

${ }^{\mathrm{x}}$ Growth index $(\mathrm{GI})=($ plant height + plant diameter $\left.) \div 2\right]$.

${ }^{\mathrm{w}}$ Primary shoot caliper (PSC) determined by measuring below the lowest axillary shoot.

${ }^{v}$ Axillary shoot number determined by counting axillary shoots $>1$ inch below the apical meristem or inflorescence.

${ }^{\mathrm{u}}$ Total plant dry mass $(\mathrm{TDM})=$ young plant dry mass $(\mathrm{YDM})+$ plant dry mass $(\mathrm{PDM})$

${ }^{t} Q u a d r a t i c(\mathrm{Q})$ response for nitrogen $(\mathrm{N})$ concentration. Nonsignificant (NS) or significant at $P \leq 0.05\left(^{*}\right)$, $0.01(* *)$, or $0.001(* * *)$.

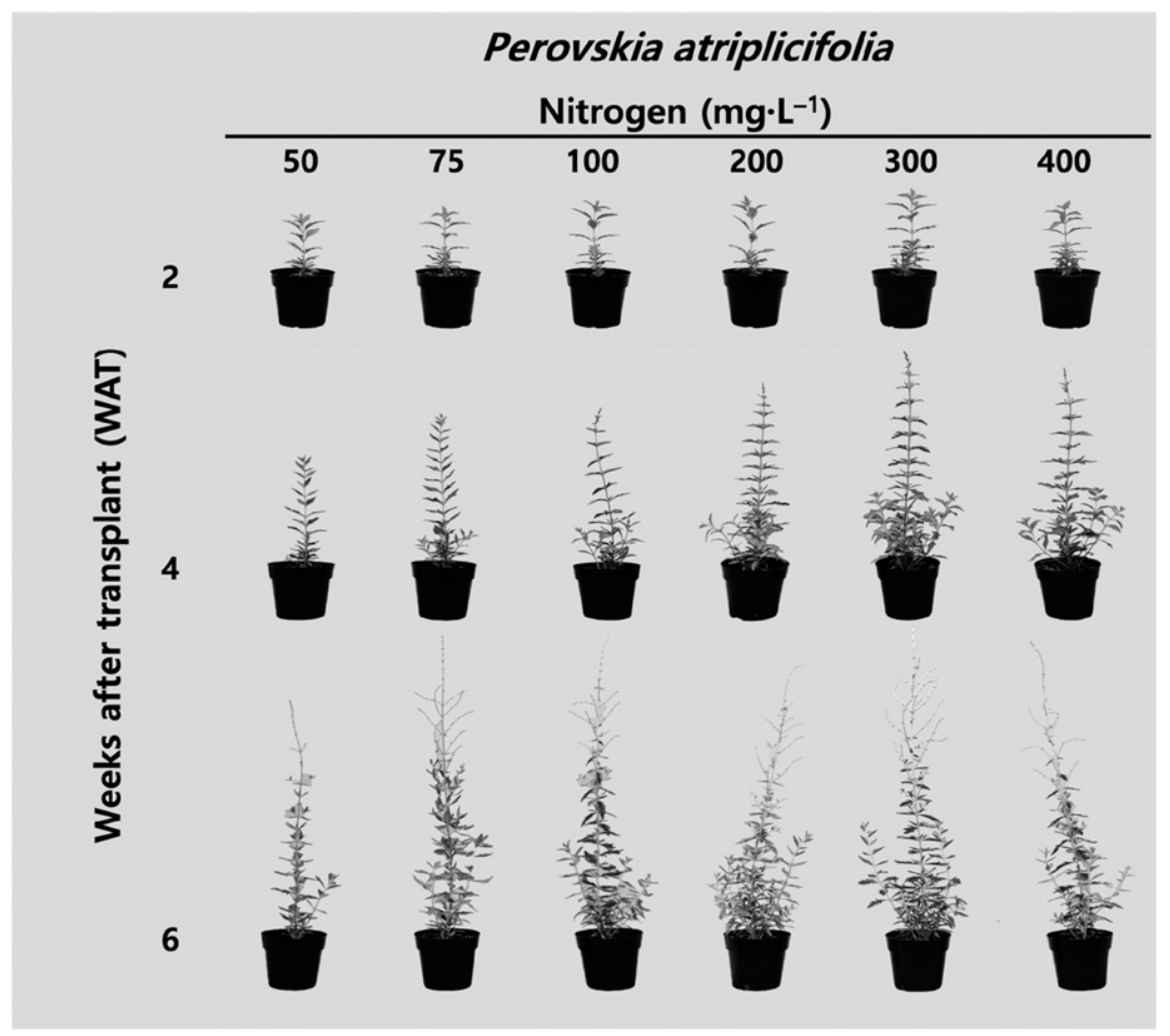

Fig. 1. Depiction of common Russian sage (Perovskia atriplicifolia Benth.) fertilized with one of six constant liquid fertilizer concentrations $\left[50,75,100,200,300\right.$, or $400 \mathrm{mg} \cdot \mathrm{L}^{-1}$ nitrogen $\left.(\mathrm{N})\right]$ based on balanced ratios of $\mathrm{N}$-phosphorous $(\mathrm{P})$-potassium $(\mathrm{K})$ and a constant level of a water-soluble micronutrient blend at 2, 4, and 6 weeks after transplant (WAT). reported smaller TDM in perennial species of Hibiscus and Heuchera cultivars provided with increasing fertilizer concentrations and EC levels more than 300 and $100 \mathrm{mg} \cdot \mathrm{L}^{-1} \mathrm{~N}$, respectively. In the current study, average substrate EC values extracted from common Russian sage grown at $400 \mathrm{mg} \cdot \mathrm{L}^{-1} \mathrm{~N}$ were $7.88 \mathrm{mS} \cdot \mathrm{cm}^{-1}$ and $28 \%$ to $76 \%$ (2.28-6.01 $\mathrm{mS} \cdot \mathrm{cm}^{-1}$ ) higher than average substrate EC values determined for plants fertilized at 100 to $200 \mathrm{mg} \cdot \mathrm{L}^{-1} \mathrm{~N}$. Average substrate EC values extracted from 'Crazy Blue' Russian sage grown at $400 \mathrm{mg} \cdot \mathrm{L}^{-1} \mathrm{~N}$ were 7.77 $\mathrm{mS} \cdot \mathrm{cm}^{-1}$ and $33 \%$ to $71 \%$ (2.59-5.51 $\mathrm{mS} \cdot \mathrm{cm}^{-1}$ ) higher than average substrate EC values determined for plants fertilized at 100 to $200 \mathrm{mg} \cdot \mathrm{L}^{-1} \mathrm{~N}$. Although plants did not exhibit lower leaf necrosis at concentrations $\geq 200 \mathrm{mg} \cdot \mathrm{L}^{-1} \mathrm{~N}$, plants did, in fact, enter a state of luxury nutrient consumption, thereby detrimentally impacting overall plant quality. When TDM and substrate EC of each taxa were considered together, $200 \mathrm{mg} \cdot \mathrm{L}^{-1} \mathrm{~N}$ was determined as the upper nutritional range limit, and plants fertilized with 300 to 400 $\mathrm{mg} \cdot \mathrm{L}^{-1} \mathrm{~N}$ were excluded from further statistical analyses. Therefore, the optimal sufficiency range for both Perovskia selections in this study was determined to be 100 to 200 $\mathrm{mg} \cdot \mathrm{L}^{-1} \mathrm{~N}$.

Sufficiency ranges for both Perovskia selections were used to determine recommended leaf tissue concentrations of 11 elements by chronological age. Similar to the results found by Owen (2019a, 2019b), lower and upper limits of recommended leaf tissue concentration ranges were defined by analyzing data for each Perovskia selection grown at 100 to $200 \mathrm{mg} \cdot \mathrm{L}^{-1} \mathrm{~N}$ over a 6 -week crop cycle. Although only one record (Biernbaum and Morrison, 2000) (Table 2) of recommended leaf tissue values for common Russian sage grown in soilless substrate exists, previous work did not establish leaf tissue concentration limits.

Macronutrients. For both Perovskia selections, leaf tissue total $\mathrm{N}\left(\mathrm{NO}_{3}{ }^{-}\right.$and $\left.\mathrm{NH}_{4}{ }^{-}\right)$, $\mathrm{P}, \mathrm{K}, \mathrm{Mg}, \mathrm{Ca}$, and $\mathrm{S}$ concentrations increased with ascending fertilizer concentrations from 100 to $200 \mathrm{mg} \cdot \mathrm{L}^{-1} \mathrm{~N}$ and at all stages of the 6week crop cycle. For instance, in young growth (2 WAT), the total N, P, and K concentrations of common Russian sage fertilized with 100 to $200 \mathrm{mg} \cdot \mathrm{L}^{-1} \mathrm{~N}$ ranged between $3.68 \%$ and $5.10 \%$ for $\mathrm{N}, 0.42 \%$ and $0.73 \%$ for $\mathrm{P}$, and $4.21 \%$ and $5.15 \%$ for $\mathrm{K}$, respectively, and increased to ranges of $5.94 \%$ to $5.98 \%$ for $\mathrm{N}, 0.84 \%$ to $1.02 \%$ for $\mathrm{P}$, and $4.86 \%$ to $6.52 \%$ for $\mathrm{K}$, respectively, in mature growth/bloom (6 WAT). When macronutrient concentrations reported here are presented against those of previous investigations, responses are nutrient-specific and/ or species-specific. Similar to the current study, Jeong et al. (2009) reported increased leaf tissue $\mathrm{N}, \mathrm{P}$, and $\mathrm{K}$ concentrations of gerbera when provided with 100 to 200 $\mathrm{mg} \cdot \mathrm{L}^{-1} \mathrm{~N}$ from transplant until the first open flower (2-8 WAT). Furthermore, Krug et al. (2010), Owen (2019a), and Henry et al. (2019) reported increasing leaf tissue $\mathrm{Ca}$ 
and $\mathrm{Mg}$ concentrations of two geranium cultivars, increasing leaf tissue $\mathrm{N}, \mathrm{P}, \mathrm{Ca}$, and $\mathrm{S}$ concentrations of two perennial hibiscus cultivars, and increasing leaf tissue N, P, K, and $\mathrm{S}$ concentrations of coleus 'Stained Glassworks Eruption', respectively. Increasing leaf tissue macronutrient concentrations observed in the current study contradict the statement of Bryson and Mills (2014) that total $\mathrm{N}, \mathrm{P}, \mathrm{K}$, and $\mathrm{S}$ concentrations decrease with the age of the tissue and plant, but they support the increasing trend of $\mathrm{Ca}$ and $\mathrm{Mg}$ concentrations. Although Perovskia selec- tions were only grown for 6 weeks and were still likely amassing nutrients, the increasing leaf tissue nutrient concentrations may have been affected by substrate $\mathrm{pH}$, fertility levels, and/or nutrient amendments, thus influencing nutrient availability and uptake from the substrate. In the current study, substrate $\mathrm{pH}$ ranged from 5.5 to 6.2 at 100 to $200 \mathrm{mg} \cdot \mathrm{L}^{-1}$ $\mathrm{N}$, respectively, which is between the optimal $\mathrm{pH}$ range of 5.4 to 6.6 for most all floriculture crops (Nelson, 2012) and 5.8 to 6.5 for herbaceous perennials (Biernbaum and Morrison, 2000) grown under greenhouse condi-

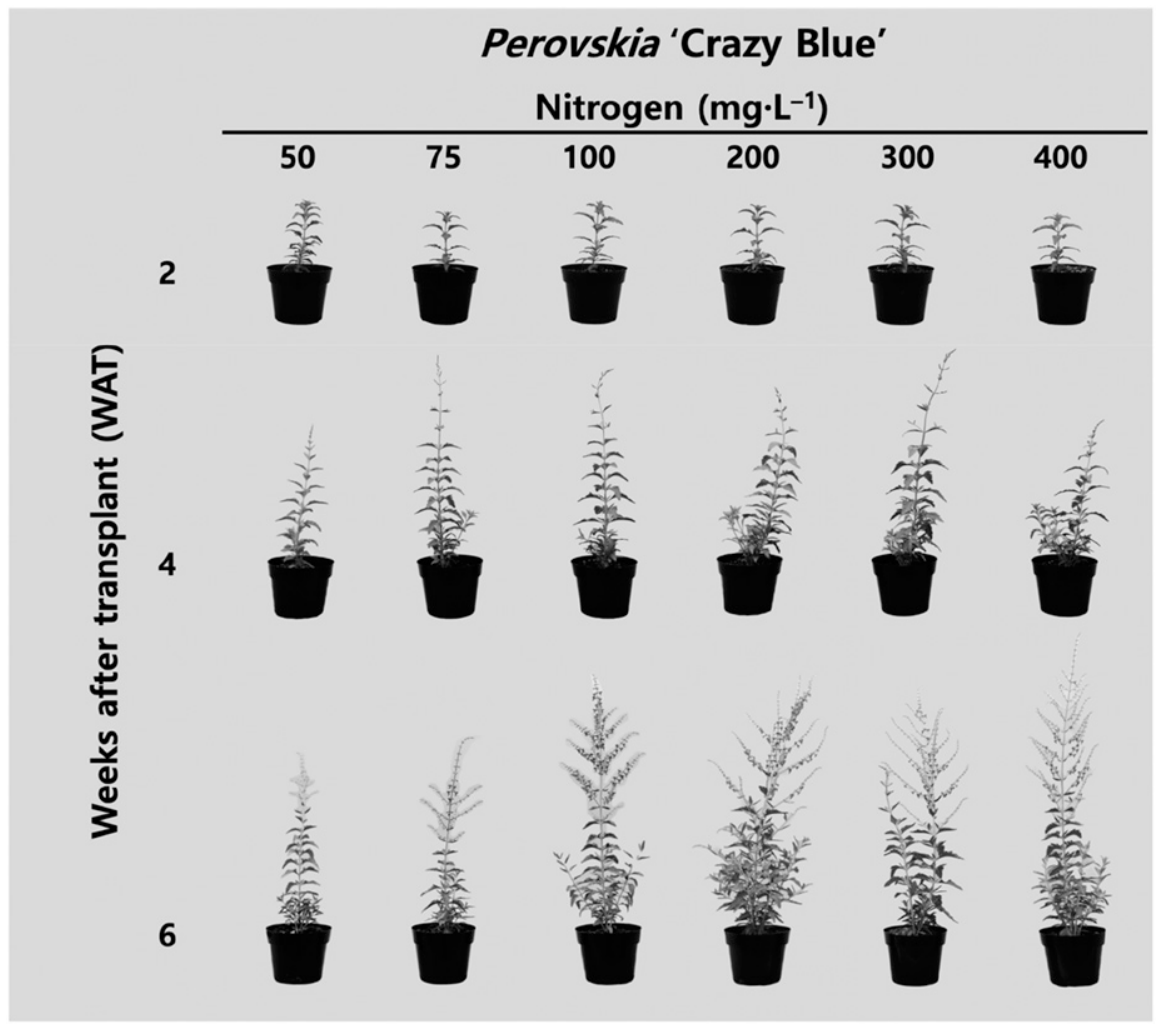

Fig. 2. Depiction of 'Crazy Blue' Russian sage (Perovskia atriplicifolia Benth.) fertilized with one of six constant liquid fertilizer concentrations $\left[50,75,100,200,300\right.$, or $400 \mathrm{mg} \cdot \mathrm{L}^{-1}$ nitrogen $\left.(\mathrm{N})\right]$ based on balanced ratios of $\mathrm{N}$-phosphorous $(\mathrm{P})$-potassium $(\mathrm{K})$ and a constant level of a water-soluble micronutrient blend at 2, 4, and 6 weeks after transplant (WAT).

tions in soilless substrates; therefore, the substrate $\mathrm{pH}$ was within the optimal range for $\mathrm{P}$ and $\mathrm{Ca}$ availability (Dole and Wilkins, 2005) and uptake. Increasing leaf tissue concentrations by chronological age of all macronutrients, specifically, $\mathrm{P}$ and $\mathrm{K}$, may indicate that plants were supplied with more nutrients than needed for their metabolic requirements (luxury consumption); therefore, the recommendations may be lower than observed in the current study for the two Perovskia selections. Increased $\mathrm{Ca}$ concentrations over the 6-week crop cycle may be attributed to increased amounts of $\mathrm{NO}_{3}{ }^{-} \mathrm{N}$ (13.1\%) compared to $\mathrm{NH}_{4}^{+}-\mathrm{N}(1.9 \%)$ provided by the fertilizer (Owen, 2019b), because $\mathrm{NO}_{3}{ }^{-}$usually increases $\mathrm{Ca}$ uptake (Bryson and Mills, 2014). Increasing tissue $\mathrm{Mg}$ concentrations may likely be attributed to the consistent volume of $\mathrm{MgSO}_{4}$ applied, as suggested by Owen (2019a; 2019b). Nonetheless, when the growth data and visual observations are considered together with the macronutrient sufficiency ranges, growth was maximized and no nutrient deficiency or toxic symptomology was observed.

Micronutrients. Upper and lower Fe, Mn, $\mathrm{Zn}, \mathrm{Cu}$, and $\mathrm{B}$ leaf concentration range limits for both Perovskia selections increased when plants were fertilized with 100 to $200 \mathrm{mg} \cdot \mathrm{L}^{-1}$ $\mathrm{N}$ from 2 to 6 WAT (young to mature growth and bloom). For instance, in young plants (2 WAT), $\mathrm{Fe}$ and $\mathrm{Mn}$ concentrations ranged between 85.5 and $95.9 \mathrm{mg} \cdot \mathrm{kg}^{-1}$ for $\mathrm{Fe}$ and between 10.8 and $31.5 \mathrm{mg} \cdot \mathrm{kg}^{-1}$ for $\mathrm{Mn}$ for 'Crazy Blue' Russian sage (Table 2). As plants matured and flowered (6 of WAT), $\mathrm{Fe}$ and Mn concentrations for 'Crazy Blue' Russian sage ranged between 186.7 and $406.7 \mathrm{mg} \cdot \mathrm{kg}^{-1}$ for $\mathrm{Fe}$ and between 34.4 and $150.8 \mathrm{mg} \cdot \mathrm{kg}^{-1}$ for $\mathrm{Mn}$. From 2 and $6 \mathrm{WAT}$ (young to maturity/bloom), the lower range limit of tissue $\mathrm{Fe}$ and $\mathrm{Mn}$ concentrations of 'Crazy Blue' Russian sage increased by $118 \%\left(101.2 \mathrm{mg} \cdot \mathrm{kg}^{-1}\right)$ for $\mathrm{Fe}$ and $219 \%$ (23.6 $\left.\mathrm{mg} \cdot \mathrm{kg}^{-1}\right)$ for $\mathrm{Mn}$ ), whereas the upper limit increased by $324 \%\left(310.8 \mathrm{mg} \cdot \mathrm{kg}^{-1}\right)$ for $\mathrm{Fe}$ and $379 \%\left(119.3 \mathrm{mg} \cdot \mathrm{kg}^{-1}\right)$ for Mn from 2 to 6 WAT (young to maturity/bloom). Leaf

Table 2. Leaf tissue survey values of 11 essential elemental nutrients for common Russian sage (Perovskia atriplicifolia Benth.) grown in soilless substrate published by Biernbaum and Morrison (2000). Sufficiency ranges of 11 essential elemental nutrients determined at 2 (young growth), 4 (active growth), and 6 (mature growth and/or bloom) weeks after transplant (WAT) for common Russian sage and 'Crazy Blue' Russian sage grown $(\mathrm{n}=6) \mathrm{under} 100-200 \mathrm{mg} \cdot \mathrm{L}^{-1}$ nitrogen $(\mathrm{N})$ based on balanced ratios of $\mathrm{N}$-phosphorous $(\mathrm{P})$-potassium $(\mathrm{K})$ supplied by $15 \mathrm{~N}-1.7 \mathrm{P}-12.5 \mathrm{~K}$ containing $1.9 \%$ ammoniacal-N and $13.1 \%$ nitrate- $\mathrm{N}$ with a constant level of water-soluble micronutrient blend.

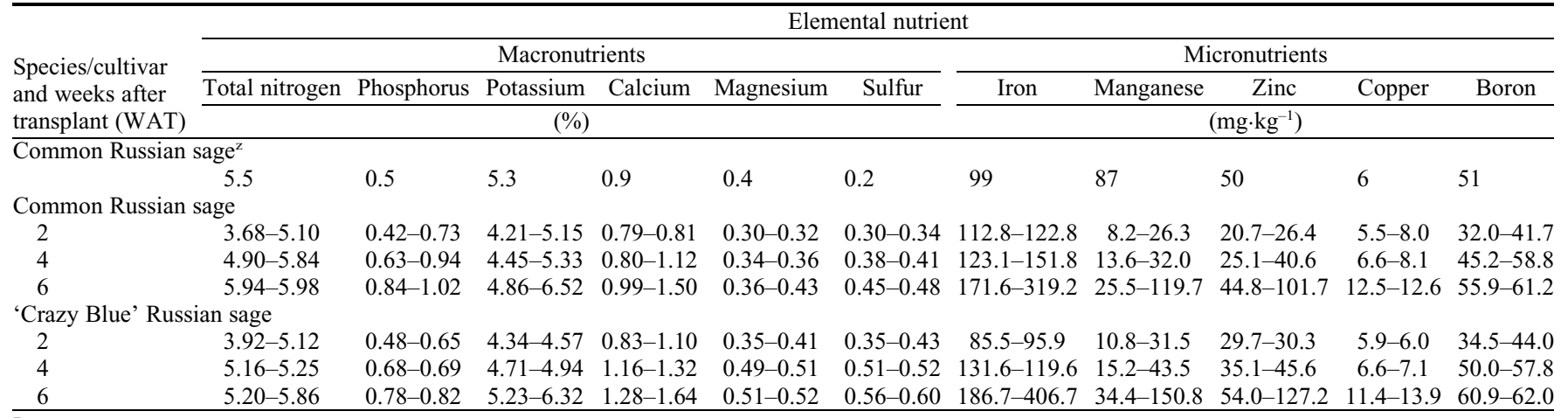

${ }^{\mathrm{z}}$ Leaf tissue survey values range for common Russian sage (Perovskia atriplicifolia Benth.) previously published by Biernbaum and Morrison (2000). 
tissue $\mathrm{Zn}, \mathrm{Cu}$, and $\mathrm{B}$ concentrations in both Perovskia selections responded similarly. When micronutrient concentrations by chronological age reported here are presented against those of previous investigations, responses are nutrient-specific and/or speciesspecific. For instance, increasing concentrations of Mn and B for gerbera (Jeong et al., 2009), of $\mathrm{Mn}, \mathrm{Cu}$, and $\mathrm{B}$ for geranium 'Tango Dark Red' (Krug et al., 2010), of $\mathrm{Mn}, \mathrm{Zn}, \mathrm{Cu}$, and $\mathrm{B}$ for perennial hibiscus cultivars (Owen, 2019a), and of $\mathrm{Fe}, \mathrm{Mn}, \mathrm{Zn}, \mathrm{Cu}$, and $\mathrm{B}$ for coleus 'Stained Glassworks Eruption' (Henry et al., 2019) were reported to increase with increasing lower and upper sufficiency ranges and by chronological age of the crop.

As plants or crops age, leaf tissue concentrations of $\mathrm{Fe}, \mathrm{Mn}$, and $\mathrm{B}$ increase and those of $\mathrm{Zn}$ and $\mathrm{Cu}$ typically decrease (Bryson and Mills, 2014). Increased accumulations of micronutrients in Perovskia leaf tissue may be the result of several factors other than plant age. For both Perovskia selections, increasing leaf tissue Fe concentration ranges may likely be the result of high $\mathrm{K}$ available in the substrate, thereby increasing the mobility and solubility of $\mathrm{Fe}$ in plants, and they may also indirectly increase the rate of Fe uptake (Bryson and Mills, 2014). However, if more plants or leaf tissue were sampled, then a dilution effect may have occurred, indicating that leaf tissue $\mathrm{Fe}$ concentrations are actually lower and within a narrower range than the ranges reported here. However, $\mathrm{Fe}$ toxicity is associated with substrate $\mathrm{pH}<5.4$; in the current study, substrate $\mathrm{pH}$ at the upper range limit $\left(200 \mathrm{mg} \cdot \mathrm{L}^{-1}\right.$ $\mathrm{N})$ was $5.5 \pm 0.1$ at 2 to $6 \mathrm{WAT}$. Therefore, elevated $\mathrm{Fe}$ concentrations may likely be attributed to excessive $\mathrm{K}$ available for plant uptake rather than substrate $\mathrm{pH}$. However, no visual $\mathrm{K}$ or $\mathrm{Fe}$ toxicity symptoms were observed. Increased Mn leaf tissue concentrations may be the result of the stimulated uptake caused by the $\mathrm{NO}_{3}^{-}$portion of the fertilizer used, although the availability of $\mathrm{Mn}$ for uptake is increased by the acidifying effect of $\mathrm{NH}_{4}^{+}$on substrate $\mathrm{pH}$ (Bryson and Mills, 2014). Overall, no micronutrient toxicity symptoms were observed as an effect of the $\mathrm{K}$ concentration, substrate $\mathrm{pH}$, or fertilizer $\mathrm{NO}_{3}{ }^{-}$.

\section{Conclusion}

For the two Perovskia selections studied, maximum growth occurred when an optimal fertility level of 100 to $200 \mathrm{mg} \cdot \mathrm{L}^{-1} \mathrm{~N}$ and a constant level of micronutrients were provided. Leaf tissue sufficiency ranges for common Russian sage and 'Crazy Blue' Russian sage by chronological age were determined and baseline ranges that did not previously exist were established. Future investigations using an acidic, basic, or neutral fertilizer source with an increasing micronutrient supply and multiple cultivars are warranted before these values are used for all Perovskia selections. Establishing nutritional requirements and establishing leaf tissue concentrations for other commercially cultivated herbaceous perennial species grown under greenhouse conditions in soilless substrates is also needed.

\section{Literature Cited}

Biernbaum, J. and M.S. Morrison. 2000. Forcing perennials: Root zone management, p. 13-16. In: Greenhouse Grower Magazine and Michigan State University (eds.). Firing up perennials: The 2000 edition. Meister Media, Willoughby, Ohio.

Bryson, G.M. and H.A. Mills. 2014. Herbaceous perennials, p. 383-413. In: G.M. Bryson and H.A. Mills (eds.). Plant analysis handbook IV. Micro-Macro Publishing, Athens, GA.

Campbell, C.R. 2000. Reference sufficiency ranges for plant analysis in the southern region of the United States. Southern Coop. Ser. Bul. 394.

Cavins, T.J. 2002. Adaptation of the PourThru nutrient extraction procedures to greenhouse crop production. North Carolina State Univ., Raleigh, PhD Diss.

Dole, J.M. and H.F. Wilkins. 2005. Nutrition, p. 94-126. In: J.M. Dole and H.F. Wilkins (eds.).
Floriculture: Principles and species. Pearson Prentice Hall, Saddle River, NJ.

Fonteno, W.C., C.T. Harden, and J.P. Brewster. 1995. Procedures for determining physical properties of horticultural substrates using the NC State University porometer. North Carolina State Univ., Hort. Substrates Lab., Raleigh, NC.

Henry, J.B., I. McCall, and B.E. Whipker. 2019 Coleus foliar nutrient sufficiency ranges and growth response to nitrogen concentrations. Acta Hort. 1266:63-70.

Jeong, K.Y., B. Whipker, I. McCall, and J. Frantz. 2009. Gerbera leaf tissue nutrient sufficiency ranges by chronological age. Acta Hort. 843:183-190.

Krug, B.A., B.E. Whipker, I. McCall, and B. Cleveland. 2010. Geranium leaf tissue nutrient sufficiency ranges by chronological age. J. Plant Nutr. 33(3):339-350.

Nelson, P.V. 2012. Fertilization, p. 261-318. Greenhouse operation and management. 7th ed. Prentice Hall, Upper Saddle River, N.J.

Owen, W.G. 2019a. Hibiscus leaf tissue nutrient sufficiency ranges by chronological age. HortScience 54:463-469.

Owen, W.G. 2019b. Leaf tissue nutrient sufficiency ranges of four Heuchera cultivars by chronological age. HortScience 54:1751-1756.

Owen, W.G. and B.E. Whipker. 2020. Target leaf tissue sampling for precise nutrient diagnosis. e-GRO Alert 9.06:1-5.

Papineau, A. and B.A. Krug. 2014. Osteospermum leaf tissue nutrient sufficiency ranges by chronological age. Acta Hort. 1034:531-538.

Pilon, P. 2006. Fertility for perennials, p. 31-78. In: P. Pilon (ed.). Perennial solutions: A grower's guide to perennial production. Ball Publishing, Batavia, IL.

Scoggins, H.L. 2005. Determination of optimum fertilizer concentration and corresponding substrate electrical conductivity for ten taxa of herbaceous perennials. HortScience 40:1504-1506.

U.S. Department of Agriculture (USDA). 2015 2014 Census of Horticultural Specialties. Nat. Agr. Sta. Service, Wash., D.C. 7 Feb. 2020. <https:// www.nass.usda.gov/Publications/AgCensus/2012/ Online_Resources/Census_of_Horticulture Specialties/HORTIC.pdf>.

Whipker, B.E., H. Landis, K. Hicks, W.G. Owen, and I. McCall. 2017. Expanding leaf tissue nutrient sufficiency standards for 74 floriculture species. Acta Hort. 1266:173-180. 